\title{
Numerical Modeling of Air Pollutants Emitted by Waterway Transportation
}

\author{
Marilia Mitidieri Fernandes de Oliveira ${ }^{1}$, Nelson Francisco Favilla Ebecken1, \\ Jorge Luiz Fernandes de Oliveira ${ }^{2}$, Marina Aires ${ }^{3}$ \\ ${ }^{1}$ Center of Technology, Federal University of Rio de Janeiro-Civil Engineering Postgraduate \\ Program-COPPE/UFRJ, Rio de Janeiro, Brazil \\ ${ }^{2}$ Geography Postgraduate Program, Geoscience Institute of Fluminense Federal University-UFF, \\ Niterói, Brazil \\ ${ }^{3}$ Meteorology Postgraduate Program, Geoscience Institute, Department of Meteorology of Federal University \\ of Rio de Janeiro-UFRJ, Rio de Janeiro, Brazil \\ Email: "marilia@coc.ufrj.br
}

Received 22 May 2016; accepted 25 June 2016; published 28 June 2016

Copyright (C) 2016 by authors and Scientific Research Publishing Inc.

This work is licensed under the Creative Commons Attribution International License (CC BY).

http://creativecommons.org/licenses/by/4.0/

(c) (i) Open Access

\section{Abstract}

The world maritime transportation is suffering a large increase in recent years and as a result of this increased on global trade, there is a consequent increase in waterway transportation and demand for fossil fuels, resulting in emissions of air pollutants. Consequently, the impact of transport emissions on climate change was put on the list of priorities. It has a high fuel demand as a result of continuous use of main engines for propulsion, electricity and heat production. The highest exposure levels of air pollution are found in ports and near them because most of the world fleet is positioned in these areas. The port of Rio de Janeiro city, in the Southeast Brazilian coastal, is inserted in the Guanabara Bay (GB), where the breezes recirculate pollutants in Metropolitan Region of Rio de Janeiro (MRRJ). Therefore, the aim of this research was to use the Brazilian Regional Atmospheric Modeling System (BRAMS) to generate the wind fields in the MRRJ and to calculate the trajectories of pollutants emitted on GB related to the waterway transportation, using a 3D kinematic trajectories model. Results demonstrated that for the periods analysed, the Central and west areas in the coastal region of the Rio de Janeiro city were the local most affected in the summer. In winter the trajectories reached the cities of the Rio de Janeiro and Duque de Caxias. Both in summer and winter, the trajectories followed towards the South Atlantic Ocean in the morning. Conclusions about this study show the need of decision-making process for better management of waterway transportation sector, improving the harmful effects on air quality in cities located in coastal regions.

\footnotetext{
${ }^{*}$ Corresponding author.
}

How to cite this paper: de Oliveira, M.M.F., Ebecken, N.F.F., de Oliveira, J.L.F. and Aires, M. (2016) Numerical Modeling of Air Pollutants Emitted by Waterway Transportation. Journal of Geoscience and Environment Protection, 4, 123-136. 


\section{Keywords}

\section{Maritime Transport, Ship Emissions, Air Pollution, Meteorological Models, Guanabara Bay}

\section{Introduction}

Emissions from the transport sector play a key role, since transport is growing fast at global scale. Transportation is an important contributor to global emissions of many different gases and aerosols that can have an impact on climate, either directly or indirectly [1]-[4]. The maritime transport sector contributes significantly to air pollution, particularly in coastal areas; however in terms of emission reduction this transport sector received less attention in the past [5]-[7]. Nowadays, climate impacts of emissions from maritime, aviation and road transports have been investigated in parallel by applying consistent methodologies, which allow direct comparison of their impact on global climate [8]. Consequently, the impact of transport emissions on climate change was put on the list of priorities [6]. The world maritime trade is suffering a large increase in recent years and as a result, there is a consequent increase in waterway transportation and demand for fossil fuels, resulting in emissions of air pollutants. Shipping emissions are currently increasing and will likely continue in the future due to the increase of global-scale trade. This modal has a potential to contribute to air quality degradation mainly in coastal areas and also to global air pollution [9].

Maritime transport contributes significantly to air pollution by the emissions of nitrogen oxides and sulphur dioxide. It has a high fuel demand as a result of continuous use of main engines for propulsion, electricity and heat production while in port. Thus, the highest exposure levels of air pollution are found in ports and near them because $80 \%$ of the world fleet is positioned in ports or navigating in coastal areas. Many people live in port cities or coastal regions with fragile ecosystems, vulnerable to the effects caused by air pollution from ships [10]. Suppliers ships used for logistical support on offshore platforms require also high density oil consumption for propulsion of the main engines and auxiliary boilers, resulting in continuous emission of pollutants. These ships are today considered one of the biggest polluters.

Gases and particles emitted from ships are a significant and growing contributor to the total emissions from the waterway transportation sector, causing degradation in human health and climate change. Regulating ship emissions requires knowledge of current fuel consumption, understanding their impact on atmospheric composition. Nearly $70 \%$ of ship emissions occur within $400 \mathrm{~km}$ of coastlines, causing air quality problems through the formation of tropospheric ozone, sulphur and particulate matter in coastal areas and harbors [11]. The main compounds emitted are Carbon Dioxide $\left(\mathrm{CO}_{2}\right)$, Nitrogen Oxides $\left(\mathrm{NO}_{\mathrm{x}}\right)$, Carbon Monoxide (CO), Volatile Organic Compounds (VOC), Sulphur Dioxide $\left(\mathrm{SO}_{2}\right)$, Black Carbon (BC) and Particulate Organic Matter (POM) [3]. Studies suggest that ships consumed around $200-290$ million metric tons $\left(1 \mathrm{Mt}=1 \mathrm{Tg}=10^{12} \mathrm{~g}\right)$ fuel and emitted around 600 - $900 \mathrm{Tg} \mathrm{CO}_{2}$ [3] [12]-[14]. These studies have estimated around 15\% of all global anthropogenic $\mathrm{NO}_{\mathrm{x}}$ emissions and $4 \%-9 \%$ of $\mathrm{SO}_{2}$ emissions attributable to ships. These emissions have a great potential to contribute significant pollution in coastal communities.

The particles can also have an indirect effect on climate through their ability to alter the properties of clouds [11]. Not only are the impacts on the global scale but also local and regional air quality in coastal areas and harbors worrying. It is necessary to improve our understanding of the impact of waterway transportation on atmospheric composition and climate and come up with suggestions for mitigation options.

In order to reduce the effects of air pollutants emission by ships on environmental and health, several measures are imposed from international, national and local legislators. In 1973, IMO (International Maritime Organization) adopted the International Convention for the Prevention of Pollution from Ships, now known universally as MARPOL, which has been amended by Protocols adopted in 1978 and 1997 and kept updated through other relevant amendments. The MARPOL Convention addresses pollution from ships by several substances, sewage, garbage, and the prevention of air pollution. MARPOL Annex VI, first adopted in 1997, limits the main air pollutants contained in ships exhaust gas, including $\mathrm{SO}_{\mathrm{x}}$ and $\mathrm{NO}_{\mathrm{x}}$, and prohibits deliberate emissions of ozone depleting substances. Actual legislation concerning $\mathrm{NO}_{\mathrm{x}}$ and $\mathrm{SO}_{\mathrm{x}}$ emissions is presented in MARPOL Annex VI [15] [16].

In addition to the challenges for society to reduce the emissions of greenhouse gases (in particular $\mathrm{CO}_{2}$ ) 
another challenge is to reduce global anthropogenic $\mathrm{NO}_{\mathrm{x}}$ and $\mathrm{SO}_{2}$ emissions that can be transported over long distances from their sources, having health and ecosystem consequences. As most marine engines operate at high temperatures and pressures, $\mathrm{NO}_{\mathrm{x}}$ and $\mathrm{SO}_{2}(2.4 \%-2.7 \%$ as average Sulphur content) emissions from ships are relatively high [17] [18]. As ocean-going ships contribute significantly to global emissions of $\mathrm{NO}_{\mathrm{x}}, \mathrm{SO}_{2}$, and POM, it was estimated that by 2020, ship emission contributions to the European Union (EU) will surpass total emissions generated by all land-based mobile, stationary and other sources in the twenty-five nations [19]. Maritime transportation is currently responsible for over $3 \%$ of global $\mathrm{CO}_{2}$ emissions, and total emissions from this sector continue to increase, reaching $5 \%$ by 2050 [20].

Economic projections indicate that containerized shipping is expected to increase throughout the world and in response to this growth; the shipping industry is expected to continue its trend toward larger container vessels [21]. The Departments of the Army, Interior, Commerce and the US Environmental Protection Agency aim to approve projects developed as mitigation plans to accommodate the larger classes of container vessels and assessment the air emissions associated with the operation of the port before and after project implementation.

The State Environmental Institute (INEA) is the agency responsible for monitoring of air quality in the state of Rio de Janeiro since 1967, when the first measurement stations were installed. The MRRJ is the region with the second largest concentration of population, vehicles, industries and emission sources of pollutants, generating serious problems of air pollution.

The resolution of the National Environment Council (CONAMA n 03/1990) indicates the air quality patterns by pollutants levels prescribed to the outside air, which cannot be exceeded in a given time and region. These parameters must be regarded for the health protection of the people, buildings and environmental resources. This Council classifies these patterns according to the exposure time, as short or long period, depending on the damage. Table 1 shows the air quality index used by the INEA based on the CONAMA resolution. The air quality patterns determined on the CONAMA related to primary and secondary patterns are shown in Table 2.

In recent years the incentives to shipbuilding in Brazil and investments for oil exploration in the sea have driven the expansion of the Brazilian fleet of marine support and port. The National Agency of Waterway Transportation (ANTAQ) with the Dutch government outlined environmental regulatory targets for this transport sector [22]. Between 2006 and 2011, the Brazilian fleet of supply ships increased from 56 to 121 vessels [23]. According to [24], emissions of air pollutants can occur for mobile sources (air, sea and land), fixed/stationary (industrial processes, power plants and others) and natural (processes occurring in vegetation, soil, marine ecosystems, volcanoes, lightning, etc.).

Reference [25] estimated emissions of $\mathrm{NO}_{2}$ and $\mathrm{SO}_{2}$ for ships anchored in GB. Simulations were made from 24 hours in pollutant plumes around the Bay for all seasons from the calculation of emissions. The worst values were on July (winter) in city of São Gonçalo in the MRRJ.

Table 1. Air quality index used by INEA according to CONAMA resolution.

\begin{tabular}{cccc}
\hline Air quality & Index & $\mathrm{NO}_{2}\left(\mu \mathrm{g} \cdot \mathrm{m}^{-3}\right)$ & $\mathrm{SO}_{2}\left(\mu \mathrm{g} \cdot \mathrm{m}^{-3}\right)$ \\
\hline Good & $0-50$ & $0-100$ & $0-80$ \\
Regular & $51-100$ & $100-320$ & $80-365$ \\
Inadequate & $101-199$ & $320-1130$ & $365-800$ \\
Bad & $200-299$ & $1130-2260$ & $800-1600$ \\
Too bad & $>299$ & $>2260$ & $>1600$ \\
\hline
\end{tabular}

Table 2. Air quality patterns determined on the CONAMA (03/90) resolution.

\begin{tabular}{cccc}
\hline Pollutant & Sampling $(\mathrm{t})$ & Primary pattern $\left(\mu \mathrm{g} \cdot \mathrm{m}^{-3}\right)$ & Secondary pattern $\left(\mu \mathrm{g} \cdot \mathrm{m}^{-3}\right)$ \\
$\mathrm{NO}_{2}$ & $24 \mathrm{~h}$ & 365 & 100 \\
$\mathrm{SO}_{2}$ & $1 \mathrm{~h}$ & 320 & 190 \\
Annual & $\mathrm{SO}_{2}$ & 80 & 40 \\
Average & $\mathrm{NO}_{2}$ & 100 & 100 \\
\hline
\end{tabular}


The pollutant plumes follow the atmospheric flow field which can be studied using the Eulerian and Lagrangian methods [26]. The Eulerian method allows a quick overview of the movement of many particle of the flow. In this method is traced tangent lines at speeds observed simultaneously at different points of the flow, called current lines. Otherwise, the Lagrangian method allows viewing the successive positions of the same particle over time. The path taken by a given air parcel for a period of time in a balanced flow is called trajectory. According [27] the knowledge of wind at the study area is not sufficient to determine the source of air masses, because the velocity vector is due to rotational movements, and not because translation of air masses. Only through the knowledge of dynamic of atmosphere is that we know the path followed by them. The calculation of air mass trajectories is very important because it enables the knowledge of pollutant emission sources transported in the atmosphere.

The above is an overview of the increase in emissions related to waterway transportation sector and its impact on air quality of coastal cities. The scope of this research is to simulate the trajectory of pollutants generated from mobile and stationary sources related to the waterway transport, using atmospheric and pollutant trajectory models. The contribution of this modal to the emission of pollutants in MRRJ is analyzed, considering a wet (summer) and dry (winter) periods.

\section{Study Area}

The study area is located on the GB, Rio de Janeiro city ( $\left.22^{\circ} 47^{\prime} 26^{\prime \prime} \mathrm{S}, 43^{\circ} 09^{\prime} 20^{\prime \prime} \mathrm{W}\right)$. The GB is surrounded by the cities of Rio de Janeiro, Duque de Caxias, São Gonçalo, Niterói and other smaller cities (Figure 1).

The GB has an estimated volume of 1.8 billion $\mathrm{m}^{3}$ in an area of about $400 \mathrm{~km}^{2}$ with a length of $28 \mathrm{~km}$ in the north-south axis, and $20 \mathrm{~km}$ at its widest point. Its depth varies from $50 \mathrm{~m}$ in the inlet connection channel with the inner shelf to less than $1 \mathrm{~m}$ in internal areas, close to the margins. This Bay is a location of marine traffic and is within the MRRJ, where is the port of Rio de Janeiro. The Brazilian fleet of maritime support is increasing and supply vessels of logistical support to oil platforms use high-density oil. These ships are considered one of the major polluters, emitting several legislated pollutants.

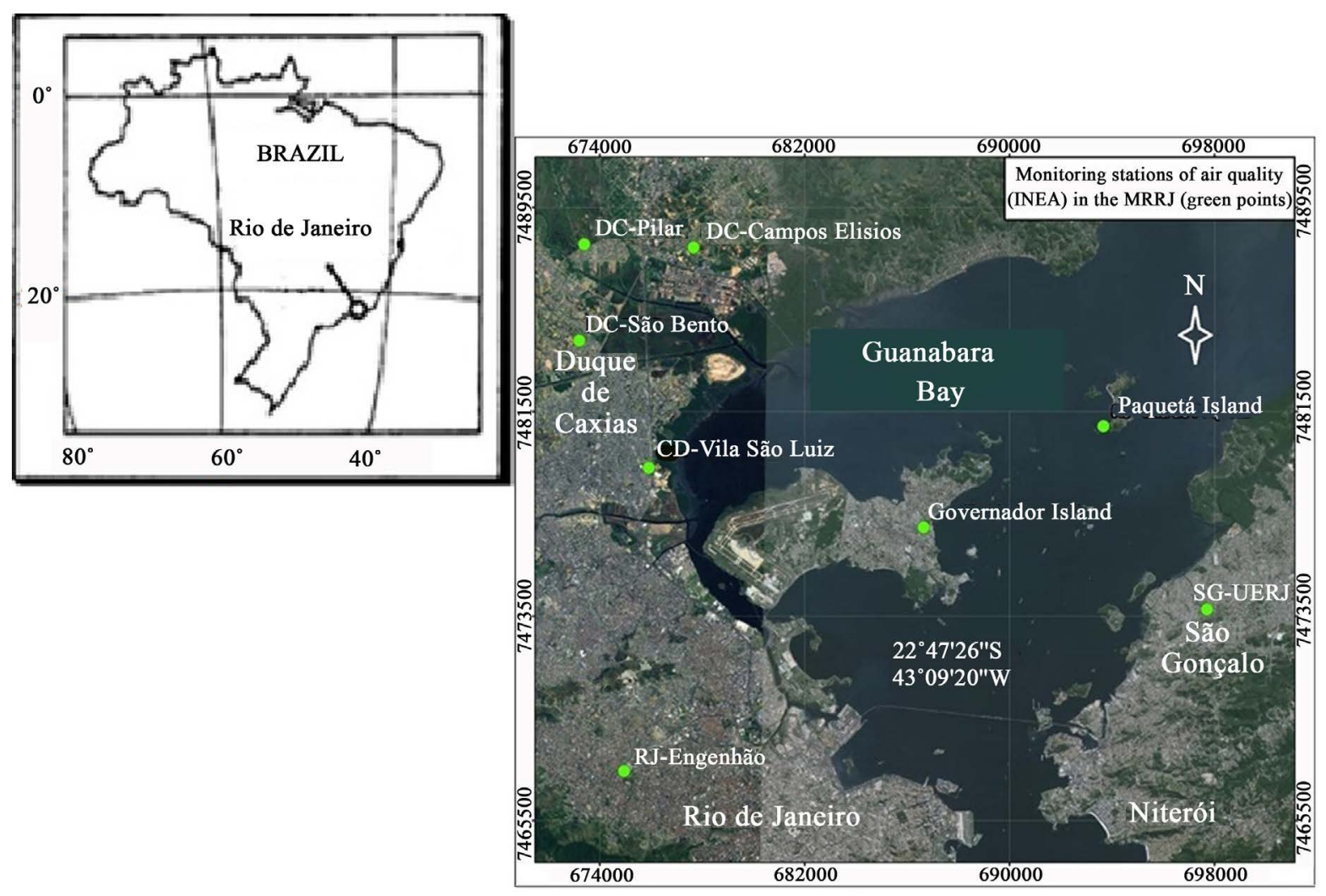

Figure 1. Map of the study area with the localization of GB. Source: Adapted from [25]. 
The region of an organized port, as in the case of Rio de Janeiro, has container terminals, steel products, vehicles (roll-on roll-off), cargo and bulks [28] [29]. Thus, emissions of air pollutants are mainly from mobile sources, generated by marine vessels and the movement of vehicles [30].

In the Marine Traffic website is possible to view several categories of ships as passenger, cargo, tankers, tug, fishing boat and other. The access to this website for the GB shows several ships of several classes as much as anchored, moving and berthed at the organized port of Rio de Janeiro (Figure 2).

The atmospheric large-scale circulation pattern over the study area refers to the general circulation of the South Atlantic with the presence of the subtropical anticyclone that is a semi-stationary meteorological system, presenting a well-defined seasonal movement. During the summer, the subtropical anticyclone over the continent becomes weaker than winter, moving southerly. On its western side the winds blow northeasterly towards the southeastern coast of South America and they are more intense in the southeastern coast of Brazil where the GB is located. This circulation is periodically disturbed by the passage of frontal systems caused by migrating anticyclones that move from the southwest across the northeast in the southeast coast of Brazil.

The differential heating between the GB and the continent generates the mesoscale meteorological phenomenon known as breeze, recirculating pollutants in MRRJ. The land breeze (during the night) follows the northsouth direction, carrying pollutants to densely urbanized regions of the coast and the sea breeze (during the day) into the metropolitan area. The MRRJ topography with the hills located parallel to the coastline acts as a physical barrier to the winds from the sea, blocking the ventilation in areas located further inland [31] [32]. At the regional scale $(100 \mathrm{~km})$, the circulation of sea breeze or land breeze caused by the temperature difference between the surface of the sea and the continent, may limit air ventilation through recirculation pollutants [33].

The MRRJ, an urban area, densely populated and industrialized has the air quality reduced. The effect of the sea breeze is verified by transporting the west side pollutants (source) to the east side (receiving region) of the MRRJ. To manage air quality of the MRRJ is necessary to know the meteorological, geographical and socioeconomic variables and the chemistry of the troposphere. Reference [25] compared the emission values of $\mathrm{NO}_{\mathrm{x}}$ and $\mathrm{SO}_{2}$ with the data of the daily bulletin monitoring air quality around the GB performed by INEA, using the [34] software. The author used the local meteorological variables, regional geomorphology, the exact position of vessels and the number of vessels on the basis of maritime traffic in real time for the period 2013-2014. After processing the database, it was verified that these pollutants emitted by ships anchored on GB have a contribution that must be considered in relation to the impact on the deterioration of air quality in MRRJ.

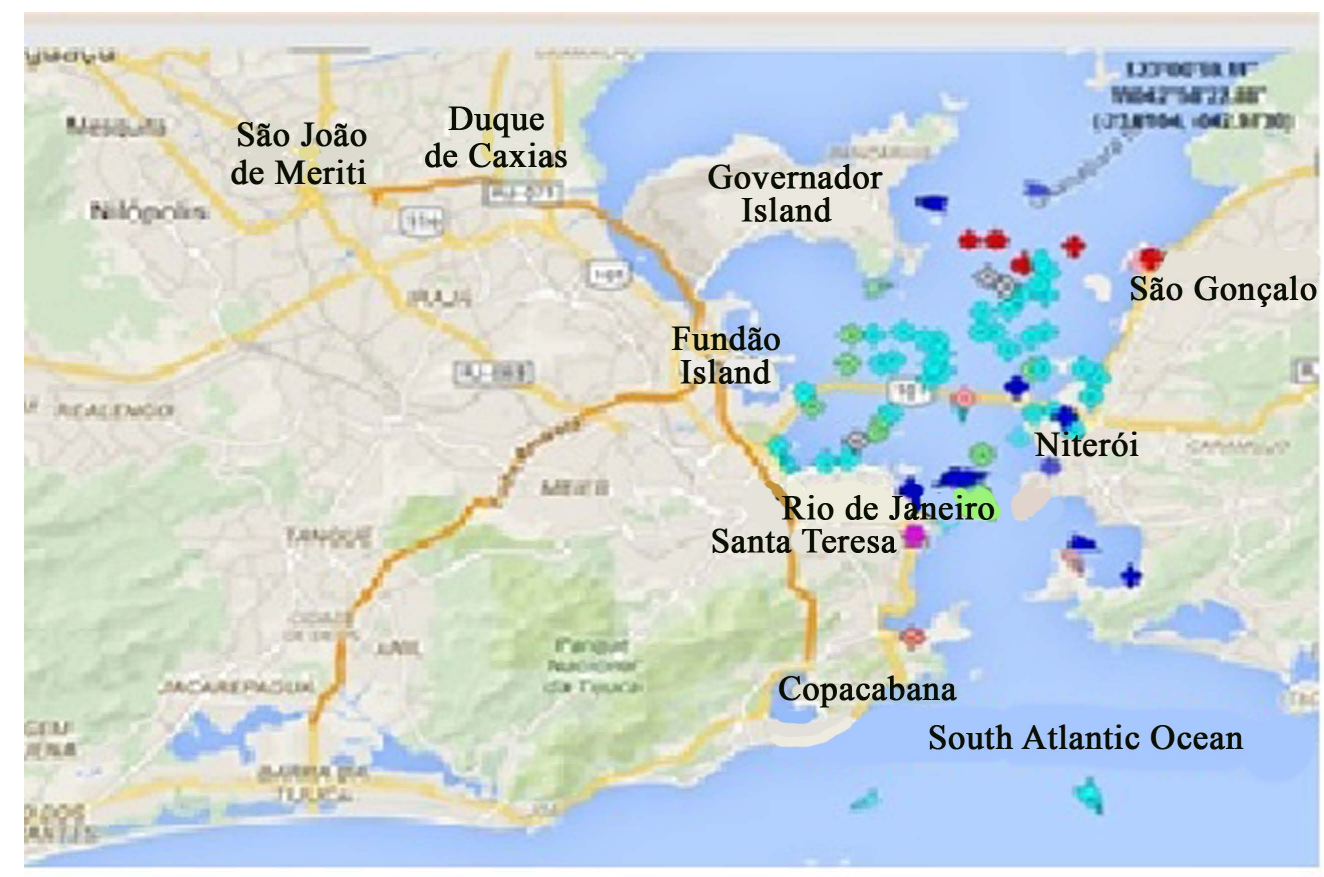

Figure 2. Map of marine traffic in GB with several types of vessel and part of the MRRJ. Source: Adapted from http://www.marinetraffic.com downloaded on May 10, 2016. 


\section{Methods}

\subsection{Meteorological Dataset}

In this research was used the Brazilian Regional Atmospheric Modeling System (BRAMS) to generate the wind fields in the area of MRRJ and to analyze the meteorological flows. This model is a set of computer program that simulates the atmosphere for weather and climate research and for numerical weather prediction [35]. The reanalysis from the National Centers for Environmental Prediction-NCEP and National Center for Atmospheric Research-NCAR [36] were used for initialization of this model for February and August, 2015.

\subsection{Atmospheric Simulations}

To perform the numerical simulations of the wind field in MRRJ it was used the BRAMS with three grids tridimensionally nested according to the studies developed by [37]. The grids used in this approach, allowed covering the domain of MRRJ, capturing the features of mesoscale patterns. The downscaling technique, consisting in reduction scales, allowed that larger scale information passed to the smaller ones and vice versa, using the two-way nesting.

The reanalysis dataset of the climatological average of February and August, 2015 were submitted to analysis package of BRAMS, which treated and interpolated the data of horizontal wind components, temperature and relative humidity at several pressure levels for isentropic and sigma_Z levels. The initial condition and boundary for numerical integrations were obtained by applying objective analysis [38] of these two dataset.

The BRAMS generated flow field to initialize the model of three-dimensional kinematic trajectories developed by [39] [40] and calculate the trajectories of pollutants emitted on the GB during summer and winter. For the model assimilate the data, in the center, the sides and in the top of the domain, it was used the Newtonian relaxation with three nested grids centered on the GB as an alternative form of dynamic initialization of the NCEP/NCAR reanalysis dataset, because this technique allows the model to reach the desired fitting after a few hours of integration. The boundary layer was finely refined with stretch ratio of 1.5.

\subsection{Calculation of Air Parcel Trajectories}

In this research it was opted for the cinematic three-dimensional model due to the existence of three-dimensional wind field, the size of the study area and the high-resolution of the grid 3 used in the MRRJ domain. The trajectories of the MRRJ air parcels were obtained at different times and heights, on February and August, in order to verify the influence of the breeze system in the trajectory of pollutants emitted in the region.

The calculation of trajectories is based on the Equation (1) [41]:

$$
\frac{d r(t)}{d t}=V(r, t)
$$

where

$r(t)$ is the position of the air parcel at time $t$;

Vis the horizontal wind field $(u, v)$ and the vertical wind $(w)$.

This model allows the knowledge of the output and arrival of trajectories in a region. From Equation (1), the position of the air parcel $r(t)$ is defined by Equation (2) to the output trajectory (forward) after the time lag $\Delta t=$ $\left(t_{1}-t_{0}\right)$ :

$$
r\left(t_{1}\right)=r\left(t_{0}\right)+\int_{t_{0}}^{t_{1}} V[r(t), t] d t
$$

The calculation of the arrival trajectory (backward) is also obtained from Equation (1).

The level (height) reached by a particle or pollutant, along the trajectory of air parcels, is represented by the color scale of the figure.

The trajectories of pollutants emitted in the area of GB were calculated forward between 0600 and 2100 local time (LT) with integration time of 3 and 6 hours for days on February 9 and August 5, 2015. To view the flow field and the trajectories of pollutants, it was used the Grids Analysis and Display System-GRADS [42]. 


\section{Results and Discussion}

The results of the atmospheric flow in MRRJ with the use of BRAMS and 3D kinematic trajectories models on February and August showed simulations for atmospheric conditions of summer (wet) and winter (dry), respectively. Once characterized the flow for these periods, it was calculated the trajectories followed by the pollutants emitted by fixed and mobile sources on the GB due to waterway transportation. The trajectories followed by pollutants emitted by these sources show the sector contribution to air quality in the MRRJ.

Figure 3 shows the passage of a frontal system (cold front) in southeastern region of Brazil on February 09, 2015 (wet period). This system changes the pattern of sea and land breezes characteristic on GB. This synoptic condition was chosen to show the influence of a frontal system on the local mesoscale system and also in the transport of pollutants generated on GB due to the waterway transportation.

The simulated wind field at 0900 LT showed a confluence of NW and NE winds, intensifying the land breeze on the GB (Figure 4(a)). As the cold front moved toward the ocean, NE winds were intensified at 1500 and $2100 \mathrm{LT}$ with speed around $10 \mathrm{~m} \cdot \mathrm{s}^{-1}$, interfering with the behavior of the sea breeze, annulling the recirculation of pollutants in the MRRJ (Figure 4(b) and Figure 4(c)).

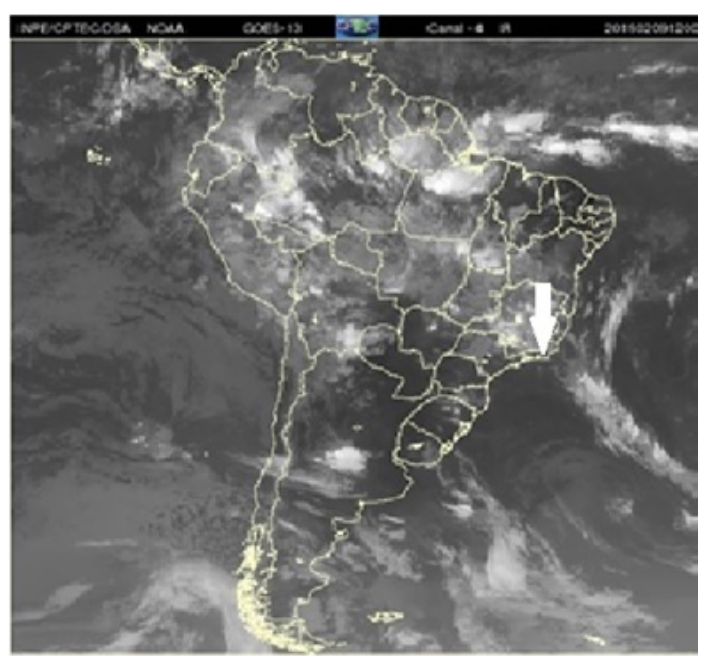

Figure 3. GOES satellite image on February 09, 2015, 0900 LT (1200 UTC), showing the passage of the cold front in the southeastern region of Brazil. The white arrow indicates the study area (state of Rio de Janeiro).

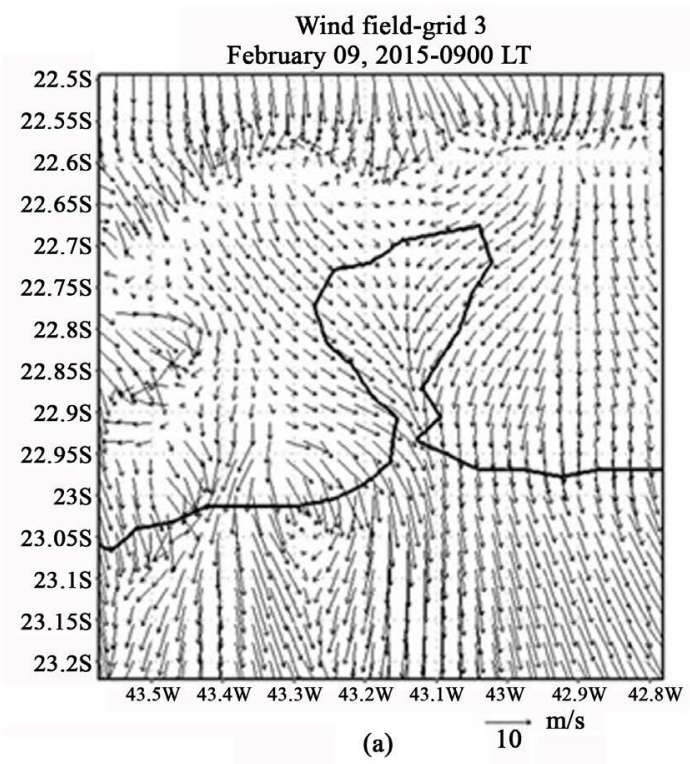




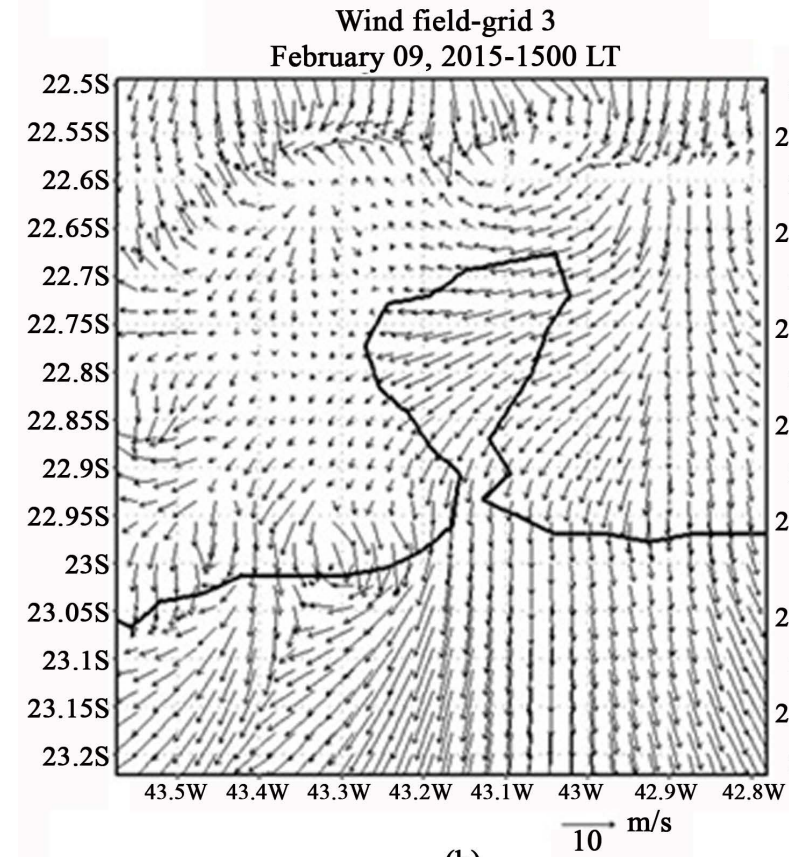

(b)

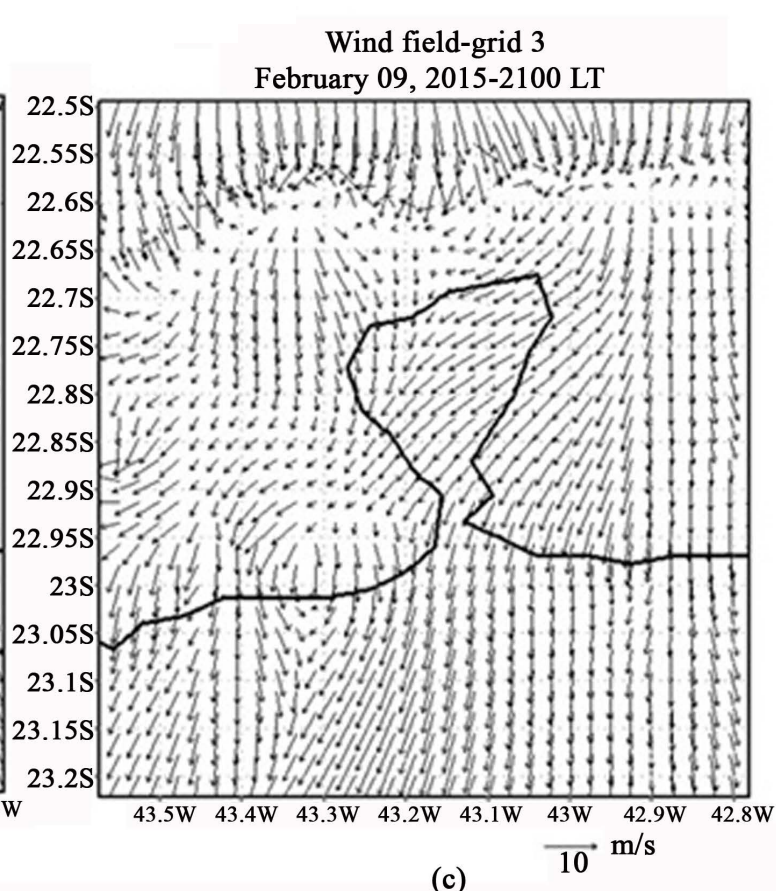

(c)

Figure 4. Wind field on February 09, 2015 at 0900 LT (a), showing the confluence of the winds on the GB, characteristic of the presence of cold fronts in the state of Rio de Janeiro. Wind field at 1500 and 2100 LT (b) and (c), respectively show NE wind direction with speed around $10 \mathrm{~m} \cdot \mathrm{s}^{-1}$ due to the deviation of the cold front toward the South Atlantic Ocean.

Figure 5 shows the trajectories calculated at 0900, 1500, 1800 and 2100 LT following SE, SW, SW and S directions, respectively, around 500 meters of height. In this scenario, pollutants were transported towards the South Atlantic Ocean, as well as in Central Rio de Janeiro and coastal areas of West zone of the city, influencing thus the air quality in this region.

The mesoscale flow type breeze occur on scales of hundreds of kilometers. These wind systems are affected by local topography and the differential heating of the surface, favoring or harming the places where they move. Temperature inversions are conditions that occur in the winter season. However, with the passage of a cold mass over the region can occur block situation caused by a high migratory pressure center. This condition is extremely unfavorable to the health of the population because maintains the pollution near the ground. Over the analyzed period it was verified that at all time simulations occurred a predominance of land breeze due to the influence of the large-scale system, favoring the MRRJ.

In the dry period from August 03-10, 2015, the synoptic condition in the MRRJ was clear sky, high temperature around $30^{\circ} \mathrm{C}$ and low relative humidity (Figure 6). This synoptic condition was chosen to calculate the trajectories of pollutants generated on the GB by waterway transport due to unfavorable atmospheric features to disperse pollutants. The presence of migratory high pressure system, acting in the Southeast region intensified the land breeze.

The simulated flow field on August 05-09, 2015 at 0900 LT showed NE winds intensifying the land breeze on the GB around $8 \mathrm{~m} \cdot \mathrm{s}^{-1}$ (Figure 7(a)); at $15 \mathrm{LT}$ showed the weakening of land breeze as a result of heating in the MRRJ (Figure 7(b)). Despite the weakening of the winds on the GB, the land breeze acted still blowing southward, carrying pollutants with less intensity to the south of GB.

Figure 8 shows the trajectories calculated on August 09 at 0900, 1500, 1800 and 2100 LT following S, W, W and SW directions, respectively. In this scenario, pollutants were transported towards the South Atlantic Ocean, as well as westward of the MRRJ, reaching the cities of Rio de Janeiro and Duque de Caxias. Pollutants following the movement of large scale winds around 500 meters of height, contributing further to the deterioration of air quality in the region.

In conditions of clear sky and calm, the cooling air near the surface is more pronounced, causing the temperature inversion. These conditions limit the lateral and vertical dispersion of the pollutants and the concentrations 
became higher. At nightfall the loss of terrestrial radiation becomes the atmosphere more stable, due to the surface cooling. As shown in Figure 8, the simulations made at 1800 and 2100 LT show the trajectories following to densely populated areas of MRRJ. Therefore, the stable atmosphere with lightwind limits the dispersion of pollutants and concentrations may rise.
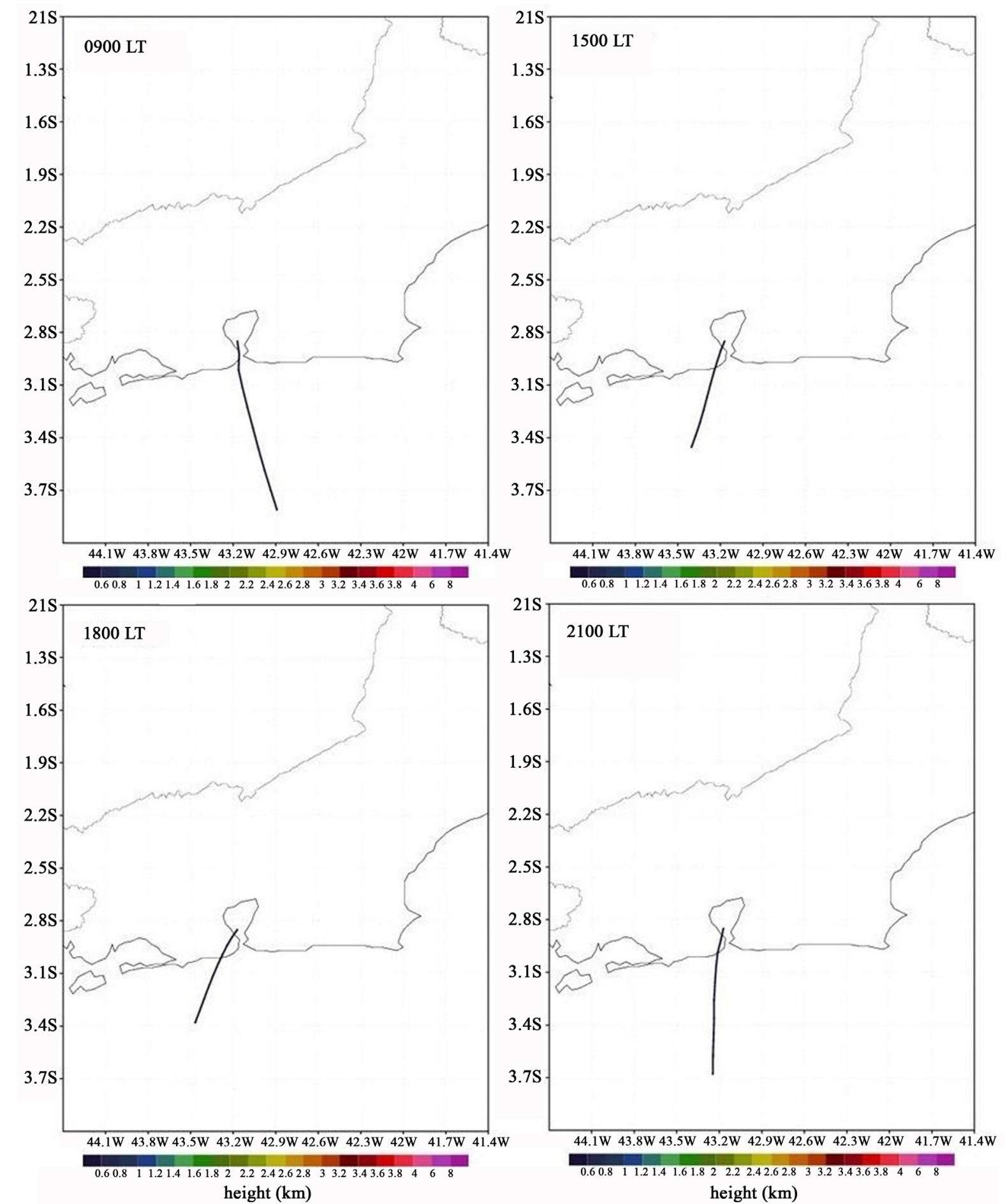

Figure 5. Trajectories of pollutants simulated with 3D kinematic model on February 09, 2015 at 0900, 1500, 1800 and 2100 LT around 500 meters of height (represented by the color scale of the figure). 


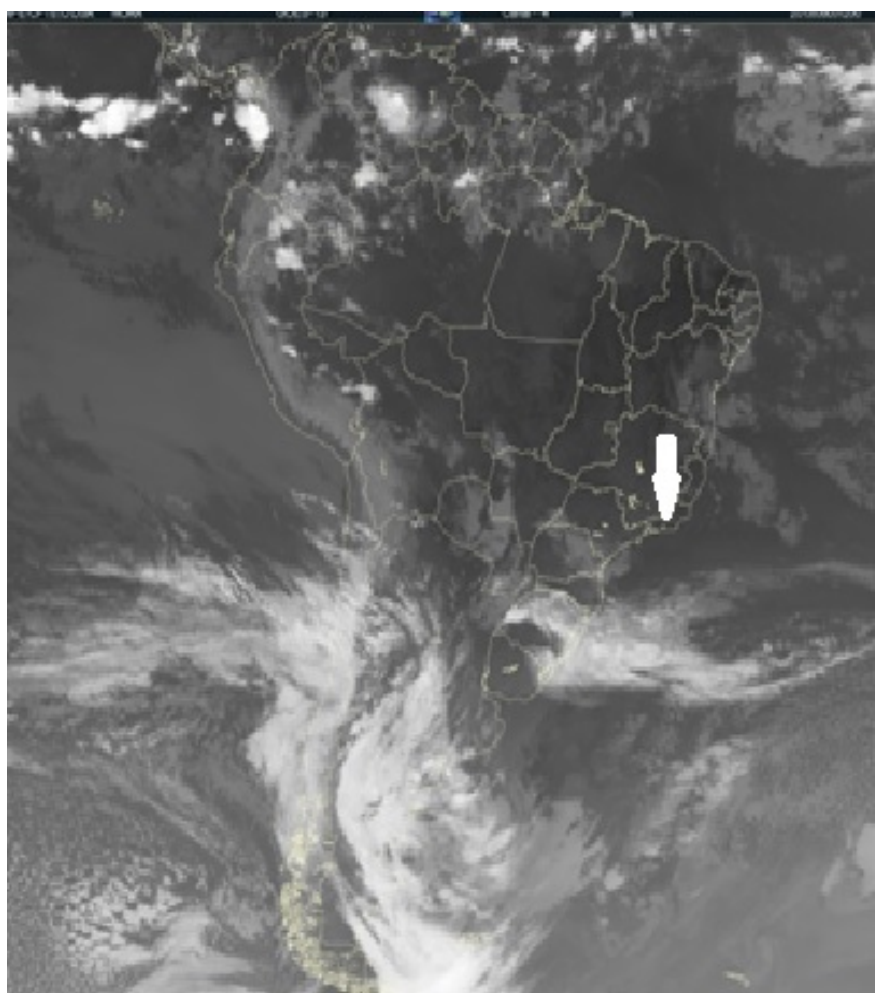

Figure 6. GOES satellite image of August 05, 2015, 0900 LH (1200 UTC), showing a large dark area of the map where is the state of Rio de Janeiro (white arrow). This area is under stable atmospheric condition with a migratory high pressure system.

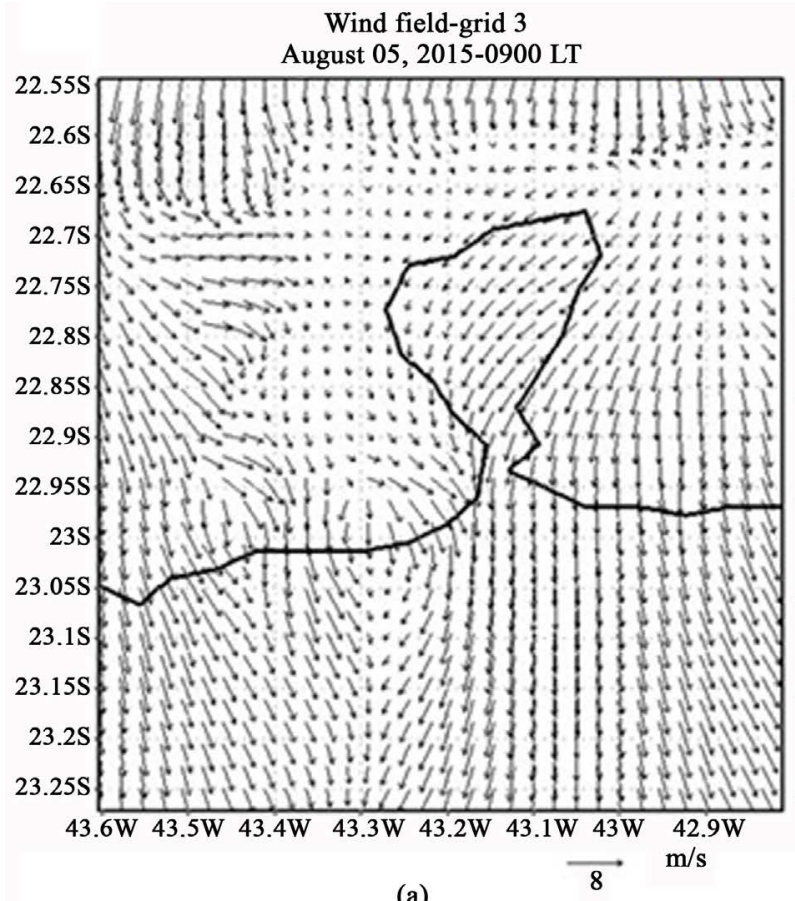

(a)

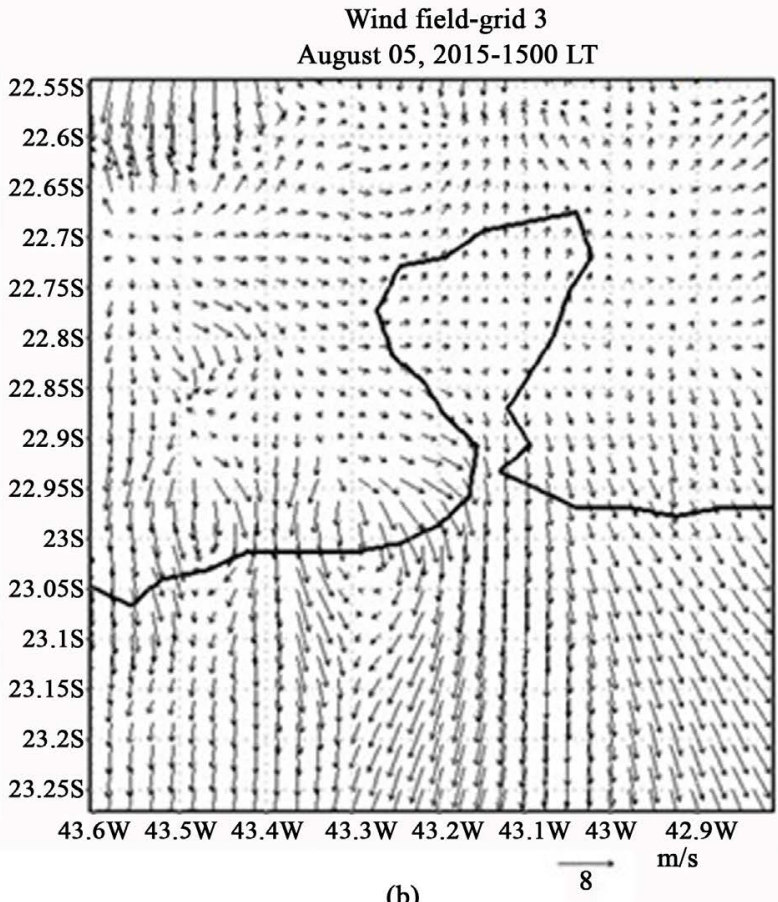

(b)

Figure 7. (a) Wind field on August 05, 2015 at 0900 LT, showing the winds blowing towards NE direction with speed around $8 \mathrm{~ms}^{-1}$ on the GB region; (b) Wind field at $1500 \mathrm{LT}$, showing the weakening of land breeze on GB, blowing with much lower speed than $8 \mathrm{~m} \cdot \mathrm{s}^{-1}$. 

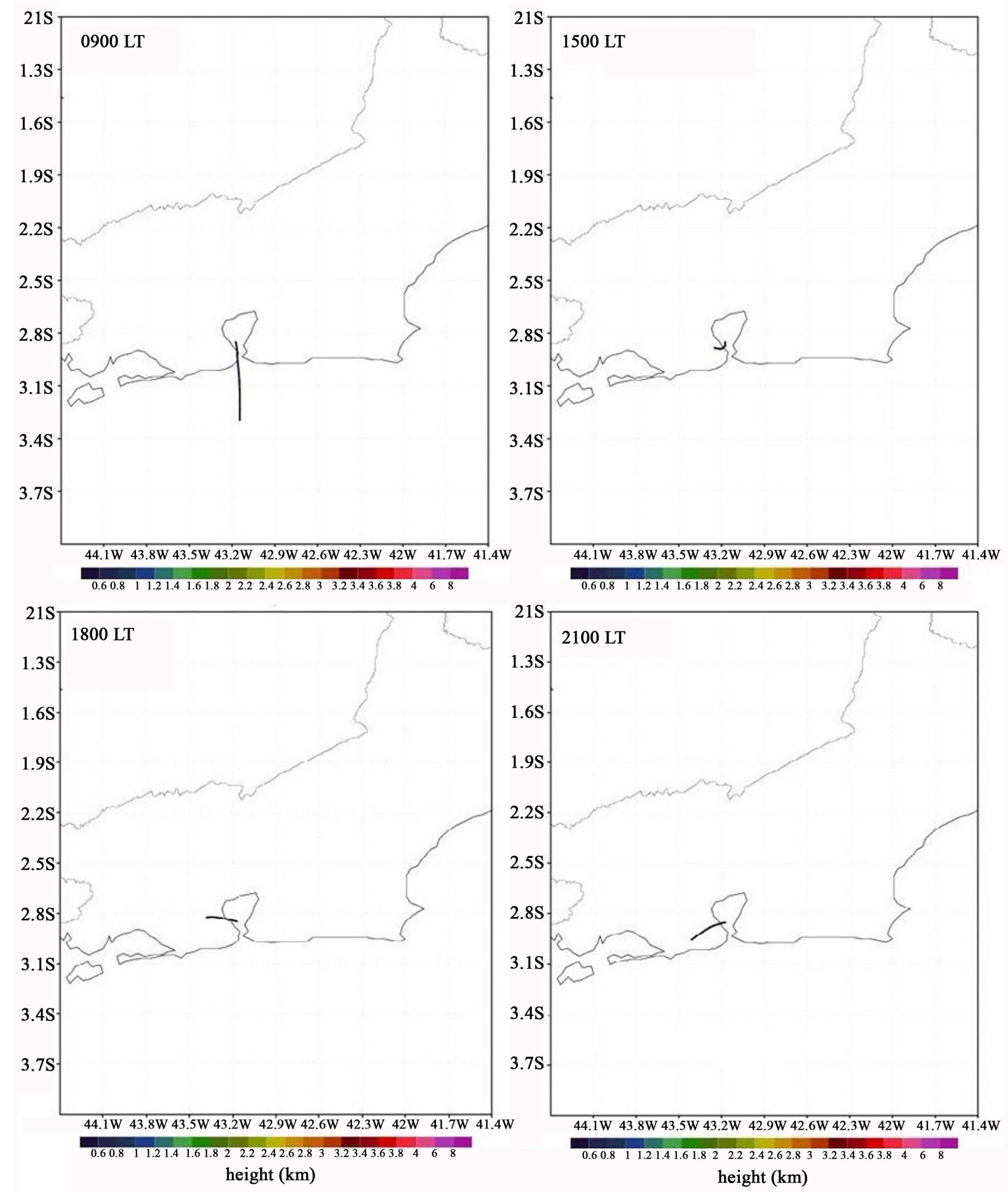

Figure 8. Trajectories of pollutants simulated with 3D kinematic model on August 09, 2015 at 0900, 1500, 1800 and 2100 LT around 500 meters of height (represented by the color scale of the figure).

\section{Conclusions}

The waterway transportation sector is increasing the fleet of ships in GB, influencing the air quality in MRRJ and vicinity. The industry of oil and natural gas in the state of Rio de Janeiro has contributed to the increase the fleet of supplier ships, used for logistical support to oil platforms. These ships are potentially pollutants due to use of low 
quality fuel. The air quality in the RMRJ has a strong influence of meteorological systems, especially type breeze, which recirculate pollutants on GB. The atmospheric modeling used in this research showed the influence of these systems on the transport of pollutants generated by the movement of vessels as well as ships at anchor in GB and berthed at the port of Rio de Janeiro for the summer and winter seasons. In the summer, the most affected points in the MRRJ were the central and coastal areas of the west side of the Rio de Janeiro city. In winter the trajectories followed in the westward of MRRJ, reaching the cities of the Rio de Janeiro and Duque de Caxias. Both in summer and winter, the trajectories followed towards the South Atlantic Ocean in the morning.

This study shows the need for better management of waterway transportation sector to improve the harmful effects on air quality in the MRRJ generated by the maritime fleet in GB. The complexity of the physical processes and their impacts must be analyzed, as well as aspects related to legislation, regulatory systems and articulation between several plans and programs of different sectors of administration. It should consider a policy that favors the required patterns for urban development without environmental degradation, aiming to preserve the air quality in cities located in coastal regions.

\section{Acknowledgements}

The authors acknowledge the financial support of the National Scientific and Technological Development Council (CNPq).

\section{References}

[1] Fuglestvedt, J.S., Berntsen, T.K., Isaksen, I.S.A., Mao, H.T., Liang, X.Z. and Wang, W.C. (1999) Climatic Forcing of Nitrogen Oxides through Changes in Tropospheric Ozone and Methane; Global 3D Model Studies. Atmospheric Environment, 33, 961-977. http://dx.doi.org/10.1016/S1352-2310(98)00217-9

[2] Ambrosino, G., Sassoli, P., Bielli, M., Carotenuto, P. and Romanazzo, M. (1999) A Modeling Framework for Impact Assessment of Urban Transport Systems. Transportation Research, Part D, 4, 73-79. http://dx.doi.org/10.1016/S1361-9209(98)00014-5

[3] Eyring, V., Kohler, H.W., van Aardenne, J. and Lauer, A. (2005) Emissions from International Shipping: 1. The Last 50 Years. Journal of Geophysical Research-Atmospheres, 110, D17305. http://dx.doi.org/10.1029/2004JD005619

[4] Fuglestvedt, J.S., Shine, K.P., Berntsen, T., Cook, J., Lee, D.S., Stenke, A., Skeie, R.B., Velders, G.J.M. and Waitz, I.A. (2010) Transport Impacts on Atmosphere and Climate: Metrics. Atmospheric Environment, 44, 4648-4677. http://dx.doi.org/10.1016/j.atmosenv.2009.04.044

[5] Corbett, J.J., Winebrake, J.J., Green, E.H., Kasibhatla, P., Eyring, V. and Lauer, A. (2007) Mortality from Ship Emissions: A Global Assessment. Environmental Science \& Technology, 41, 8512-8518. http://dx.doi.org/10.1021/es071686z

[6] Brüning, C. (2010) Transport Impacts on Atmosphere and Climate. Atmospheric Environment, 44, 45-46. http://dx.doi.org/10.1016/j.atmosenv.2010.04.018

[7] Sausen, R. (2010) Transport Impacts on Atmosphere and Climate. Atmospheric Environment, 44, 46-47. http://dx.doi.org/10.1016/j.atmosenv.2010.02.033

[8] Heal, M.R., Kumarbc, P. and Harrisonde, R.M. (2012) Particles, Air Quality, Policy and Health. Chemical Society Reviews, 41, 6606-6630. http://dx.doi.org/10.1039/c2cs35076a

[9] Viana, M., Hammingh, P., Colette, A., Querol, X., Degraeuwe, B., Vlieger, I. and van Ardenne, J. (2014) Impact of Maritime Transport Emissions on Coastal Air Quality in Europe. Atmospheric Environment, 90, 96-105. http://dx.doi.org/10.1016/j.atmosenv.2014.03.046

[10] van der Meer, R. (2012) Marine Air: Shipping Emissions in Ports and Their Impact on Local Air Quality: A Case Study on the Ports of Delfzijl and Eemshaven. Netherlands: Faculty of Mathematics and Natural Science, Groningen University. http://www.rug.nl/research/portal/files/2433545/2012-05.pdf

[11] Eyring, V., Isaksen, I.S.A., Berntsen, T., Collins, W.J., Corbett, J.J., Endresen, O., Grainger, R.G., Moldanova, J., Schlager, H. and Stevenson, D.S. (2010) Transport Impacts on Atmosphere and Climate: Shipping. Atmospheric Environment, 44, 4735-4771. http://dx.doi.org/10.1016/j.atmosenv.2009.04.059

[12] Corbett, J.J. and Koehler, H.W. (2003) Updated Emissions from Ocean Shipping. Journal of Geophysics Research, 108, 4650. http://dx.doi.org/10.1029/2003JD003751

[13] Endresen, O., Sorgard, E., Sundet, J.K., Dalsoren, S.B., Isaken, I.S.A., Berglen, T.F. and Gravir, G. (2003) Emission from International Sea Transportation and Environmental Impact. Journal of Geophysics Research, 108, 4560. http://dx.doi.org/10.1029/2002JD002898 
[14] Endresen, O., Sørgård, E., Behrens, H.L., Brett, P.O. and Isaksen, I.S.A. (2007) A Historical Reconstruction of Ships Fuel Consumption and Emissions. Journal of Geophysical Research, 112, 301. http://dx.doi.org/10.1029/2006JD007630

[15] IMO (2011) Annex VI, Chapter 3. MARPOL 73/78/97. International Maritime Organization, London, 266-267. http://www.imo.org/en/Publications/Documents/Newsletters and Mailers/Mailers/id520e.pdf

[16] IMO (2011) Prevention of Air Pollution from Ships. http://www.imo.org/en/OurWork/environment/pollutionprevention/Pages/Default.aspx

[17] EPA-Environmental Protection Agency, USA (2000) Analysis of Commercial Marine Vessels Emission and Fuel Consumption Data. Rep. EPA420-R-00-002.

[18] Endresen, O., Bakke, J., Sorgard, E., Berglen, T.F. and Holmvang, P. (2005) Improved Modelling of Ship $\mathrm{SO}_{2}$ Emissions-A Fuel Based Approach. Atmospheric Environment, 39, 3621-3628. http://dx.doi.org/10.1016/j.atmosenv.2005.02.041

[19] ICCT (The International Council on Clean Transportation) (2007) Air Pollution and Greenhouse Gas Emissions from Ocean-Going Ships: Impacts. Mitigation Options and Opportunities for Managing Growth. http://www.theicct.org/sites/default/files/publications/oceangoing_ships_2007.pdf

[20] Sardinha, A. (2013) Poluição e Transporte Marítimo. Colecção Mar Fundamental (Referência CMF0012013), Lisboa. https://transportemaritimoglobal.files.wordpress.com/2013/08/poluic3a7c3a3o-e-o-tra

[21] IPCC (2014) Climate Change 2014: Mitigation of Climate Change. Contribution of Working Group III to the Fifth Assessment Report of the Intergovernmental Panel on Climate Change. Chapter 8 (Transport). Cambridge University Press, Cambridge. https://www.ipcc.ch/pdf/assessment-report/ar5/wg3/ipcc_wg3_ar5_full.pdf

[22] Fialho, F, (2010) Waterway Transportation as a Logistic and Environmental Solution-Meeting of the Permanent Brazil-Netherlands Workgroup for Cooperation in the Port Sector-ANTAQ, Palácio do Itamaraty, Brazil. http://www.antaq.gov.br/portal/pdf/palestras/antaq2010apr09dgfialho-palestramre-itamarati.pd

[23] ANTAQ (2011) Raios-X da frota brasileira na navegação de apoio marítimo-Principais empresas e suas frotas. http://www.antaq.gov.br/portal/pdf/BoletimPortuario/FrotaApoioMaritimo2011.pdf

[24] IEMA (2014) Instituto de Energia e Meio Ambiente: $1^{\circ}$ diagnóstico da rede de monitoramento da qualidade do ar no Brasil. http://www.forumclima.pr.gov.br/arquivos/File/Rosana/Diagnostico_Qualidade_do_Ar_Versao_Final_Std.pdf

[25] De Paula, R. (2015) Emissões de $\mathrm{NO}_{x}$ e $\mathrm{SO}_{2}$ por embarcações do tipo supply boat fundeadas no Porto do Rio de Janeiro e o impacto na qualidade do ar. MSc Thesis, Federal University of Rio de Janeiro, Rio de Janeiro. http://dissertacoes.poli.ufrj.br/dissertacoes/dissertpoli1380.pdf

[26] Oliveira, J. L. F. de. (2004) Análise espacial e modelagem atmosférica: Contribuições ao gerenciamento da qualidade do ar da Bacia Aérea III da Região Metropolitana do Rio de Janeiro. Ph.D. Thesis, Federal University of Rio de Janeiro, Rio de Janeiro. http://www.coc.ufrj.br/index.php/teses-de-doutorado/148-2004/978-jorge-luiz-fernandes-de-oliveira

[27] Doty, K.G. and Perkey, D.J. (1993) Sensitivity of Trajectory Calculations to the Temporal Frequency of Wind Data. Monthly Weather Review, 121, 387-401. http://dx.doi.org/10.1175/1520-0493(1993)121<0387:SOTCTT>2.0.CO;2

[28] Tostes \& Medeiros Engenharia. (2007) Estudo de adequação do plano de desenvolvimento e zoneamento do Porto do Rio de Janeiro. Relatório, Rio de Janeiro.

[29] Tostes \& Medeiros Engenharia (2009) Plano de Desenvolvimento e Zoneamento do Porto do Rio de Janeiro: Plano de Adequação.

[30] ICF (2009) Current Methodologies in Preparing Mobile Source Port-Related Emission Inventories. https://archive.epa.gov/sectors/web/pdf/ports-emission-inv-april09.pdf

[31] INEA (2009) Instituto Estadual do Ambiente. Relatório anual da qualidade do ar do estado do Rio de Janeiro. http://www.inea.rj.gov.br/cs/groups/public/@inter_dimfis_gear/documents/document/zwff/mde3/ edisp/inea_017061. pdf

[32] INEA (2013) Instituto Estadual do Ambiente. Relatório anual da qualidade do ar do estado do Rio de Janeiro. http://www.inea.rj.gov.br/cs/groups/public/@inter_dimfis_gear/documents/document/bmvh/mdey/ edisp/inea012571.p $\underline{\mathrm{df}}$

[33] Luhar, A.K. and Hurley, P.J. (2004) Application of a Prognostic Model TAPM to Sea-Breeze Flows, Surface concentrations, and Fumigating Plumes. Environmental Modelling \& Software, 19, 591-601. http://dx.doi.org/10.1016/j.envsoft.2003.08.011

[34] AIRMOD, Description of model formulation (2004) Developted by U.S. Environmental Protection Agency—EPA. https://www3.epa.gov/scram001/7thconf/aermod/aermod_mfd.pdf

[35] BRAMS—Brazillian Regional Atmospheric Modeling System. http://www.brams.cptec.inpe.br

[36] Kistler, R. and Coauthors (2001) The NCEP-NCAR 50-Year Reanalysis: Monthly Means CD-ROM and Documen- 
tation. Bulletin of the American Meteorological Society, 82, 247-267. http://journals.ametsoc.org/doi/pdf/10.1175/1520-0477\%282001\%29082\%3C0247\%3ATNNYRM\%3E2.3.CO\%3B2 http://dx.doi.org/10.1175/1520-0477(2001)082<0247:TNNYRM>2.3.CO;2

[37] Clark, T.L. and Farley, R.D. (1984) Severe Downslope Windstorm Calculations in Two and Three Spatial Dimensions Using Anelastic Interactive Grid Nesting: A Possible Mechanism for Gushiness. Journal of the Atmospheric Sciences, 41, 329-350. http://dx.doi.org/10.1175/1520-0469(1984)041<0329:SDWCIT>2.0.CO;2

[38] Barnes, S.L. (1973) Mesoscale Objective Map Analysis Using Weighted Time Series Observations. NOAA Tech Memo, NSSL, 62-68.

[39] Freitas, S.R., Longo, K.M., Dias, M.A.F. and Artaxo, P. (1996) Numerical Modeling of Air Mass Trajectories from the Biomass Burning Areas of the Amazon Basin. Anais da Academia Brasileira de Ciências, 68, 193-206. https://www.researchgate.net/publication/257875020

[40] Freitas, S.R. (1999) Modelagem numérica do transporte e das emissões de gases traços e aerossóis de queimadas no Cerrado e Floresta Tropical da América do Sul. Ph.D. Thesis, University of São Paulo, São Paulo. http://bdtd.ibict.br/vufind/Record/USP_e372ff9fbd538f8c9100b8deae4049cc

[41] Petterssen, S. (1956) Weather Analysis and Forecasting. 2nd Edition, Vol. I, McGraw-Hill Book Co., Inc., New York.

[42] Doty, B. (1995) The Grid Analysis and Display System-GrADS, v 1.5.1.12. http://www.funceme.br/modelagem/echam46/mar2013-2/GrADS_doc_1_5_1.pdf

\section{Submit or recommend next manuscript to SCIRP and we will provide best service for you:}

Accepting pre-submission inquiries through Email, Facebook, Linkedin, Twitter, etc A wide selection of journals (inclusive of 9 subjects, more than 200 journals) Providing a 24-hour high-quality service User-friendly online submission system Fair and swift peer-review system Efficient typesetting and proofreading procedure Display of the result of downloads and visits, as well as the number of cited articles Maximum dissemination of your research work

Submit your manuscript at: http://papersubmission.scirp.org/ 